\title{
FDI Effects To Host Country's Technological Progress: Evidence From Albanian Manufactoring Industry
}

\author{
Aurel Koroci, Dr \\ Albanian University/ Head of Department of Economic Sciences, Albania \\ Erjona Deshati, Msc \\ Albanian University/ Department of Economic Sciences Assistant, Albania \\ Remzi Sulo, Asoc.Prof \\ Albanian University/ Dean of the Faculty of Applied and Economic \\ Sciences, Albania \\ doi: 10.19044/esj.2016.v12n13p134 URL:http://dx.doi.org/10.19044/esj.2016.v12n13p134
}

\begin{abstract}
Foreign direct investment (FDI) is perhaps one of the most ambiguous and the least understood concepts in international economics. Common debate on FDI is confounded by several myths regarding its nature and impact on capital accumulation, technological progress, industrialization and growth in emerging and developing economies (Akyüz, 2015). In this circumstance, the purpose of this paper is to explore empirically the impact of Foreign Direct Investment (FDI) on technological progress of Albanian manufacturing industry sectors. We also investigate the effect of FDI on domestic output, namely, whether there is evidence that the inflow of foreign capital crowds out domestic output. Using panel data analysis the empirical part of the paper finds indications that the introduction of FDI has a positive effect on the output of domestic enterprises, that is, FDI has improved the productivity and the technology upgrading of local enterprises.
\end{abstract}

Keywords: FDI, host country, technological progress, panel data

\section{Introduction}

The crucial role played by the technological progress in the economic growth is now widely accepted (Romer, 1994). With the rapid expansion of international trade and international capital flows in the global economy, the effect of FDI on the host economy, particularly on technological progress, has been of great interest to both academics and governments, and remains a contentious issue. Many scholars have studied about FDI effect to host country's technological progress and they have generated mixed results. 
Some studies have found that FDI plays a positive impact for the host country's technological progress, particularly in developing countries, in which FDI has technological spillover effects (Aitken \&Harrison, 1999; de Mello, 1999). However, some scholars study does not support FDI technology spillover effect (Damijan et al, 2001; Ewert, 2012; Feng, 2014). Looking at a deeper level, some scholars believe that different countries have different technological absorptive capacity; therefore FDI technology spillover effect in various regions is different. From this point of view, the research aims to ascertain the role of FDI to technological process in Albania.

\section{Data and Methodology}

Analysis has been carried out using data which were obtained from INSTAT and Bank of Albania. The data represent annual time series of 2010-2015 domestic manufacturing enterprises total capital (million USD), domestic manufacturing enterprises output (million USD), domestic manufacturing enterprises employee (persons number) and manufacturing enterprises total capitals (million USD) on six sub-industries of Albanian manufacturing (Food and related Producing; Cloth, shoes and related manufacturing; Chemicals and related manufacturing; Minerals and metals Manufacturing; Equipments and Other manufacturing).

In this study we use the panel data model to investigate about the role of FDI in technological progress in Albania. Comparing with the traditional analysis methods such as cross-sectional data and time-series data, the panel data model, which combines these two models together, is one kind of economical model that analyzes the relationship between variables and predicts the trend by panel data analysis. This model can reflect the variation of time and direction at the same time, and the characteristics in different time and different unit. The panel data model is a comprehensive utilization of the sample information, which makes the research more in-depth, while reducing the impact of multicolinearity. Based on the panel data we chosen, we use the software called Eviews5 and conduct the regression analysis by the method of Generalized Least Squares (GLS).

\section{Literature Review: FDI effects to local mechanism of technological progress}

More domestic and foreign scholars have analyzed foreign direct investment (FDI) enterprises spillover effect on host country's technology and this research literature focuses on two aspects: first, if it exists FDI spillover effects on the host country enterprises; second, which are local technological factors impacting spillover effects of FDI. Researches made by Caves (1974) on Australia, Globerman (1979) on Canada, and Flores Jr. And 
others (1999) on Portugal's manufacturing results show that foreign direct investment has clearly spillovers effects on host economy's industry. However, Haddad and Harrsion (1993) Monaco, Aitken and Harrison (1999) on Venezuela, and Haskel et al (2002) study of Britain's manufacturing industry has reached opposite conclusion that foreign direct investment doesn't have spillover effects within the industry. Scholars on these different studies conclusion say that foreign direct investment spillover effects within the industry are not automatically generated; host country's environment and the characteristics of different industries have an impact on the spillover effect (Chen Taotao, 2003).

Specifically, what factors influence FDI impact on technology spillover effect? Kokko (1994) study shows that in manufacturing sector in Mexico labor productivity is determined by the two co-decision mechanism of foreign and local enterprises and spillover effect in the industry is generated according to the proportion of foreign investment rate. Perez (1997) thinks that spillover effects of FDI are related to the technological gap between foreign and domestic enterprises. When the level of technology gap between them is at a certain range, FDI spillover effects increase as technology gap increase within this certain range, local businesses have some ability to learn and copy the foreign technology used; but beyond this range because of the gap the local enterprises are unable to absorb foreign advanced technology, so the spillover effects of FDI becomes very small, and it may even have a negative impact, so it creates "development threshold effect." Kokko et al (1996) on Uruguay's research shows that compared with the export-oriented foreign-funded enterprises, the host country marketoriented foreign businesses have higher spillover effect on technology. Except the ratio of FDI, other factor which influence the technology spillover effect are existing technical level, type of foreign enterprises, economic openness, basic infrastructure, existing local industrial structure and other factors (He Jie, 2000).

In general, FDI technology spillover effects to local enterprises mechanisms are summarized in the following four areas: demonstration and imitation effects, competition effects, linkages effects between companies and employees’ mobility effect.

\section{Demonstration and imitation}

During the process of FDI inflows to the host country, in general, multinational corporations will enter the local market with more advanced production equipment, new products and service models, as well as more advanced technology into, but also may bring new management skills during production process, also bringing new ideas to product marketing process, and all these things make host country's local companies to imitate 
and adapt these new things, so it brings more significant imitation and copying effects.

When the FDI enterprises and the host of local enterprises compete with each other, producing similar products or provide similar services in the process, over time, local businesses tend to take similar production technologies multinational corporations (Jenkins, 1990).

\section{Competitive effect}

In a market where trade barriers are still strong and foreign investment companies enter host country, it will strengthen the market competition in the market, foreign competition will force local firms to be more effective in using existing technology and resources, or seek new and more effective technologies to maintain its market share, so competition promotes technological upgrading in local firms, it also increases the social welfare level. FDI inflows to certain industries improve the efficiency of resource allocation.

\section{Effects of contacts between companies.}

Contact between firms generate spillover effects of industrial chain by the upstream and downstream relationship, which can be divided into the forward linkage and backward linkage where forward linkage is a relation between FDI enterprises and local enterprises, where local companies provide services such as marketing, semi-finished products or components or raw materials re-processing and other services for the foreign-funded enterprises; backward linkage is relation between FDI enterprises and local suppliers, which means that local enterprises provide raw materials for products needed for the production of foreign-funded enterprises.

In a research made by Aitken and Harrison (1991) for spillover effects of forward linkage relationships, FDI after flowing into local industry chain, it provides a high level of related intermediate products, thus it contributes to the local upstream and downstream enterprises to adopt more advanced technology and equipment, in order to have higher levels of productivity.

Therefore, foreign capital enterprises can lead host country enterprise to improve through product quality and production efficiency and promote transfer of relevant technology to local enterprises and the host country's R\&D industry development. Transnational corporations in order to achieve their high technical standards and ensure the quality of their products have more stringent acceptance criteria for the raw materials or semi-finished products and components, so local enterprises who cooperate with them have to review their stringent supplier qualification, which promotes local 
suppliers technological improvements and efficiency, and so, it improves the technological level of the host country enterprises.

\section{Labor Mobility effect}

Transnational companies effect host country's productivity not only through the machinery, equipment, patents, foreign managers and technical staff to their offices of technology transfer, but also by training local employees employed by the local branch. Such training involves employees at all levels, both the quality supervisor of simple production and the more complex production quality, including senior technical experts and senior management experts. They use different form and variety of training, including on-site guidance, seminars, training assignment, even going to the investor country to receive systematic education. These employees while working in the foreign investor country accumulate a variety of relevant skills and when these employees leave the multinational companies go and work for local firms or start their own companies, so local companies also will learn the various techniques and production technologies, so it will bring technology spillover effect (Han Gang, 2007).

\section{Data Analysis}

The variables used in this empirical analysis are as follows:

(A) The total output of domestic enterprises [Yd]: industry funded domestic enterprises industrial output value (current prices) minus industryfunded foreign enterprises gross industrial output value (current prices).

(B) The capital stock of domestic enterprises [Kd]: the total assets of industrial enterprises within the industry (current prices) minus the total assets of foreign enterprises within the industry (current prices).

(C) The amount of labor in domestic enterprises [Ld]: the number of manufacturing enterprises workers in Albania, namely, the number of domestic manufacturing enterprises workforce.

(D) The number of foreign capital [Kf]: the total assets of foreign enterprises within the industry (current prices).

The quantitative analysis data sources are coming from data provided by INSTAT and Bank of Albania database from 2010 to 2015.

In order to find a better Panel Data, we have conducted a covariance analysis test by using the related data. The test mainly focuses on two hypotheses:

$$
H_{1}: \alpha_{i}=\alpha_{j}, \quad \beta_{i}=\beta_{j} ; \quad H_{2}: \beta_{i}=\beta_{j} \text { 。 }
$$

The test conducted by two F-statistics, the statistics for $H_{1}$ is:

$$
F_{1}=\frac{\left(S_{3}-S_{1}\right) /[(N-1)(k+1)]}{S_{1} /[N(T-k-1)]} \sim F[(N-1)(k+1), N(T-k-1)]
$$


And the statistics for $\mathrm{H}_{2}$ is:

$$
F_{2}=\frac{\left(S_{2}-S_{1}\right) /[(N-1) k]}{S_{1} /[N(T-k-1)]} \sim F[(N-1) k, N(T-k-1)]
$$

S1, S2, S3 in F-statistics represents the residual sum of squares estimated separately by coefficient model, variable intercept model and constant coefficient model without individual influence; $\mathrm{N}$ shows the number of sample cross-section unit; $\mathrm{T}$ means the sequential phases and $\mathrm{k}$ is the number of explanatory variables.

If the value of $\mathrm{F} 1$ is less than the corresponding critical value of $\mathrm{F}$ distribution under the given confidence level, then $\mathrm{H} 1$ is accepted, that the sample data are consistent with the constant coefficient model without individual impact, there's no need to continue to test. Otherwise continue to test H2. If the value of F2 is less than the corresponding critical value of $\mathrm{F}$ distribution under the given confidence level, then $\mathrm{H} 2$ is accepted, that the sample data are consistent with the variable intercept model. Otherwise, think the sample data are consistent with the coefficient model.

The result of sample data test is showed in tab.1.

Since $F 1=1.9082<F(0.05)(20,12)=2.54$ we accept that the Panel Data model is consistent with the constant coefficient model without individual impact.

\begin{tabular}{|c|c|c|c|}
\hline S1 & S2 & S3 & F1 \\
\hline 2.4135 & 8.5179 & 10.0893 & 1.9082 \\
\hline
\end{tabular}

Based on the analysis as above, we give the Panel Data model of testing the spillover effects of FDI enterprises on Albania manufacturing industry is as follows:

$$
\operatorname{Ln} Y_{d(i, t)}=c+\alpha \operatorname{LnK} K_{d(i, t)}+\beta \operatorname{LnL} L_{d(i, t)}+\gamma \operatorname{LnK} K_{f(i, t)}+\mu_{i, t}
$$

$i=1,2, \ldots, 6$; presents the cross-section unit of sub-sectors in manufacturing industry.

Based on the panel data we chosen, run the software called Eviews5, conduct the regression analysis by the method of Generalized Least Squares (GLS), the result are showed in tab.2.

Tab.2 The regression analysis result of the spillover effects of FDI enterprises on Albania manufacturing industry

Panel Data

\begin{tabular}{c|c|c|c|c}
\hline & $\begin{array}{c}\text { Parameter } \\
\text { estimates }\end{array}$ & $\begin{array}{c}\text { Standard } \\
\text { error }\end{array}$ & $T$ statistics & $\begin{array}{c}\text { Associated } \\
\text { probability }\end{array}$ \\
\hline$C$ & 0.7608 & 0.3152 & 2.4137 & 0.0132 \\
\hline$A$ & 0.4162 & 0.1274 & 3.2669 & 0.0000 \\
\hline
\end{tabular}




\begin{tabular}{|c|c|c|c|c|}
\hline$B$ & 0.4591 & 0.1521 & 3.0184 & 0.0000 \\
\hline$\Gamma$ & 0.0827 & 0.0307 & 2.6938 & 0.0000 \\
\hline $\begin{array}{c}\text { R-squared } \\
\begin{array}{c}\text { Adjusted R- } \\
\text { squared }\end{array}\end{array}$ & 0.9246 & \multicolumn{2}{|c|}{ F-statistic } & 73465.27 \\
\hline \multicolumn{3}{|c|}{ Eurbin-Watson stat } & 1.92 \\
\hline
\end{tabular}

From tab.2, the Panel Data got a very well overall goodness of fit, and each variable coefficient estimates has already pass the t-test, it suggested that the model can reflect the spillover effects of FDI enterprises on all of Albania manufacturing industry sectors. From 2010 to 2015, the technology spillover effect of FDI on the manufacturing industry of Albania is, if the accumulation of capital of foreign invested enterprises increased by $1 \%$, it can drive to an output growth by $0.082 \%$ in domestic enterprises in Albania's manufacturing industry. It indicates that the introduction of FDI has a positive effect on the output of domestic enterprises, that is, FDI has improved the productivity and the technology upgrading of local enterprises.

\section{Conclusion}

With the rapid expansion of international trade and international capital flows in the global economy, the effect of FDI on the host economy, particularly on technological progress, has been of great interest to both academics and governments, and remains a contentious issue. More domestic and foreign scholars have analyzed foreign direct investment (FDI) enterprises spillover effect on host country's technology. Looking at a deeper level, some scholars believe that different countries have different technological absorptive capacity; therefore FDI technology spillover effect in various regions is different. From this point of view, the research aims to ascertain the role of FDI to technological process in Albania. In general, FDI technology spillover effects to local enterprises mechanisms are summarized in the following four areas: demonstration and imitation effects, competition effects, linkages effects between companies and employees' mobility effect. Referring to the panel data analysis we used in this study concluded these findings: (1) From 2010 to 2015, the technology spillover effect of FDI on the manufacturing industry of Albania is, if the accumulation of capital of foreign invested enterprises increased by $1 \%$, it can drive to an output growth by $0.082 \%$ in domestic enterprises in Albania's manufacturing industry. (2) It indicates that the introduction of FDI has a positive effect on the output of domestic enterprises, that is, FDI has improved the productivity and the technology upgrading of local enterprises. 


\section{References:}

Arrow, J. K. (1962) The economic implications of learning by doing, Review of Economic Studies, 29 (3), 155-73.

Cecchini, L. and, Lai-Tong, C. (2008) The links between openness and productivity in Mediterranean countries, Applied Economics, 40, 685-697.

Ewert, P. J., \& Sibulele, Z. (2010). The contribution of FDI, technology and $R \& D$ to spillovers in industrial development: A south african firm-level investigation. Managing Global Transitions, (4), 341-359.

Feng, W. \& Xu, K. N. (2014). Does FDI have spillover effect on improving regional productivity? Finance and Economics,(2), 114-121

Foreign direct investment and the matching concept: developing model on downstream effect; Yitbarek Takele, Adewale Adeniyi-kie; European Scientific Journal, Vol 9, No 7 (2013).

Görg, H. and Greenaway, D. (2004) Much Ado About Nothing: Do Domestic Firms Really Benefit from Foreign Direct Investment, World Bank Research Observer, 19, 171-197.

Görg, H. and Strobl, E. (2001) Multinational Companies and Productivity Spillovers: A Meta Analysis, The Economic Journal, 111, 723-739.

Goto, A., Suzuki, K. (1989) R\&D capital, rate of return on R\&D investment and spillover of R\&D in Japanese manufacturing industries, Review of Economics and Statistics, 71 (4), 555-564.

Hubert, F. and Pain, N. (2000) Inward Investment and Technical Progress in the UK Manufacturing Sector, OECD Economics Department Working Papers No. 268, OECD, Paris.

Managi, S. and Bwalya, S. M. (2010) Foreign direct investment and technology spillovers in sub-Saharan Africa, Applied Economics Letters, 17, 605-608.

Schumpeter, J. (1934) The Theory of Economic Development, Harvard University Press: Cambridge, USA.

Schumpeter, J. (1939) Business Cycles, Porcupine Press: Philadelphia.

Tian, X. (2007) Accounting for sources of FDI technology spillovers: evidence from China, Journal of International Business Studies, 38, 147-159. Uzawa, H. (1965) Optimum technical change in an aggregative model of economic growth, International Economic Review, 6 (1), 18-31.

Van Pottelsberghe de la Potterie, B. and Lichtenberg, F. (2001) Does Foreign Direct Investment Transfer Technology across Borders?; Review of Economics and Statistics, Vol. 83, pp. 490-497

Wang, C. and Yu, L. (2007) Do spillover benefits grow with rising foreign direct investment? An empirical examination of the case of China, Applied Economics, 39, 397-405. www.bankofalbania.org 


\begin{tabular}{|c|c|c|c|c|c|c|}
\hline A & B & C & D & $E$ & $\mathrm{~F}$ & G \\
\hline \multirow{2}{*}{6 sub manufacturing industries } & \multicolumn{6}{|c|}{ total assets of industrial enterprises within the industry } \\
\hline & 2010 & 2011 & 2012 & 2013 & 2014 & 2015 \\
\hline food and related producing & 175.2 & 216.5 & 311.6 & 367.3 & 391.6 & 401.7 \\
\hline cloth,shoes and related manufacturing & 265.5 & 360.2 & 499.6 & 552.2 & 674.6 & 685.2 \\
\hline chemicals and related manufacturing & 101.2 & 164.4 & 194.2 & 221.6 & 276.7 & 290.8 \\
\hline minerals and metals manifacturing & 112.3 & 126.2 & 223.2 & 251.5 & 311.4 & 326.4 \\
\hline equipments & 32.6 & 47.8 & 65.6 & 79.4 & 98.3 & 102.9 \\
\hline other manufacturing & 72 & 106 & 141.5 & 146.7 & 173.2 & 181.3 \\
\hline Sourc & $\mathrm{k}$ of & ania & & & & \\
\hline
\end{tabular}

\begin{tabular}{|c|c|c|c|c|c|c|}
\hline A & $\mathrm{H}$ & 1 & $\mathrm{~J}$ & $\mathrm{~K}$ & $\mathrm{~L}$ & M \\
\hline \multirow{2}{*}{6 sub manufacturing industries } & \multicolumn{6}{|c|}{ capital stock of domestic enterprises } \\
\hline & 2010 & 2011 & 2012 & 2013 & 2014 & 2015 \\
\hline & & & & & & \\
\hline food and related producing & 141 & 198.2 & 271.8 & 320.6 & 365.5 & 392.3 \\
\hline cloth,shoes and related manufacturing & 227.1 & 311.4 & 436 & 509.6 & 610 & 667.8 \\
\hline chemicals and related manufacturing & 86.3 & 150.2 & 181.4 & 210.7 & 234.3 & 256.7 \\
\hline minerals and metals manifacturing & 98.4 & 104.6 & 191.7 & 235.8 & 280.6 & 306.7 \\
\hline equipments & 23.4 & 38.5 & 54.2 & 63.6 & 89.4 & 95.8 \\
\hline other manufacturing & 60 & 91.4 & 123.8 & 130.6 & 165.8 & 172.4 \\
\hline Sourc & ak of $t$ & bania & & & & \\
\hline
\end{tabular}

\begin{tabular}{|c|c|c|c|c|c|c|}
\hline A & $\mathrm{N}$ & 0 & $P$ & Q & $\mathrm{R}$ & S \\
\hline \multirow{2}{*}{6 sub manufacturing industries } & \multicolumn{6}{|c|}{ number of domestic manufacturing enterprises workforce } \\
\hline & 2010 & 2011 & 2012 & 2013 & 2014 & 2015 \\
\hline food and related producing & 11286 & 14894 & 18675 & 21972 & 24293 & 25678 \\
\hline cloth,shoes and related manufacturing & 19678 & 25239 & 30892 & 35659 & 37561 & 38243 \\
\hline chemicals and related manufacturing & 7239 & 9156 & 11765 & 13231 & 15123 & 15340 \\
\hline minerals and metals manifacturing & 11253 & 12845 & 13525 & 14562 & 16893 & 17256 \\
\hline equipments & 3576 & 4943 & 5221 & 6700 & 6927 & 7102 \\
\hline other manufacturing & 8165 & 10673 & 12675 & 14293 & 15752 & 17050 \\
\hline
\end{tabular}




\begin{tabular}{|c|c|c|c|c|c|c|}
\hline 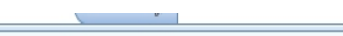 & & & & & & \\
\hline A & T & U & V & W & $\mathrm{x}$ & Y \\
\hline \multirow{2}{*}{6 sub manufacturing industries } & \multicolumn{6}{|c|}{ total assets of foreign enterprises within the industry } \\
\hline & 2010 & 2011 & 2012 & 2013 & 2014 & 2015 \\
\hline & & & & & & \\
\hline food and related producing & 50 & 60.8 & 88.3 & 88.5 & 111.2 & 145.9 \\
\hline cloth,shoes and related manufacturing & 104.8 & 136.5 & 190.2 & 215 & 235.9 & 236.3 \\
\hline chemicals and related manufacturing & 30.9 & 40.8 & 33.4 & 33 & 37.4 & 37.1 \\
\hline minerals and metals manifacturing & 43.2 & 60.7 & 70 & 65.6 & 81.5 & 85.2 \\
\hline equipments & 9.8 & 16 & 17.8 & 20.5 & 19.6 & 24.4 \\
\hline other manufacturing & 48 & 60.6 & 77.8 & 90.7 & 66 & 75.1 \\
\hline \multicolumn{7}{|c|}{ Source: CEIC, Bank of Albania } \\
\hline \multicolumn{7}{|c|}{ Source: CEIC, Bank of Albania } \\
\hline
\end{tabular}

\section{Data Panel on six sub-industries of Albanian manufacturing}

\begin{tabular}{|c|c|c|c|c|c|c|c|c|c|c|c|c|}
\hline \multirow{5}{*}{$\begin{array}{l}\text { Six sub- } \\
\text { industries }\end{array}$} & \multicolumn{6}{|c|}{$\begin{array}{l}\text { Domestic manufacturing enterprises total } \\
\text { capital } \\
\text { (million USD) }\end{array}$} & \multicolumn{6}{|c|}{$\begin{array}{l}\text { Domestic manufacturing enterprises } \\
\text { output (million USD) }\end{array}$} \\
\hline & 2 & 2 & 2 & 0 & 0 & 2 & 2 & 2 & 2 & 0 & 0 & 2 \\
\hline & 0 & 0 & 0 & 0 & 0 & 0 & 0 & 0 & 0 & 0 & 0 & 0 \\
\hline & 1 & 1 & 1 & 1 & 1 & 1 & 1 & 1 & 1 & 1 & 1 & 1 \\
\hline & 0 & 1 & 2 & 3 & 4 & 5 & 0 & 1 & 2 & 3 & 4 & 5 \\
\hline \multirow{4}{*}{$\begin{array}{l}\text { Food and } \\
\text { related } \\
\text { Producing }\end{array}$} & 1 & 2 & 3 & 3 & 3 & 4 & \multirow{4}{*}{$\begin{array}{l}1 \\
4 \\
1\end{array}$} & 1 & 2 & 3 & 3 & 3 \\
\hline & 7 & 1 & 1 & 6 & 9 & 0 & & 9 & 7 & 2 & 6 & 9 \\
\hline & 5 & 6 & 1 & 7 & 1 & 1 & & 8 & 1 & 0 & 5 & 2 \\
\hline & $\dot{j}$ & 5 & 6 & 3 & 6 & $\dot{7}$ & & 2 & 8 & 6 & 5 & 3 \\
\hline \multirow{4}{*}{$\begin{array}{l}\text { Cloth, shoes } \\
\text { and } \\
\text { related } \\
\text { manufacturing }\end{array}$} & 2 & 3 & 4 & 5 & 6 & 6 & 2 & 3 & & 5 & & 6 \\
\hline & 6 & 6 & 9 & 5 & 7 & 8 & 2 & 1 & 4 & 0 & 6 & 6 \\
\hline & 5 & 0 & 9 & 2 & 4 & 5 & 7 & 1 & 3 & 9 & 1 & 7 \\
\hline & 5 & 2 & $\dot{6}$ & 2 & 6 & $\dot{2}$ & $i$ & 4 & 6 & $\dot{6}$ & 0 & 8 \\
\hline \multirow{4}{*}{$\begin{array}{l}\text { Chemicals and } \\
\text { related } \\
\text { manufacturing }\end{array}$} & 1 & 1 & 1 & 2 & 2 & 2 & \multirow{4}{*}{$\begin{array}{l}8 \\
6 \\
3\end{array}$} & 1 & 1 & 2 & 2 & 2 \\
\hline & 0 & 6 & 9 & 2 & 7 & 9 & & 5 & 8 & 1 & 3 & 5 \\
\hline & 1 & 4 & 4 & 1 & 6 & 0 & & 0 & 1 & 0 & 4 & 6 \\
\hline & 2 & 4 & 2 & 6 & 7 & 8 & & 2 & 4 & 7 & 3 & 7 \\
\hline \multirow{4}{*}{$\begin{array}{l}\text { Minerals and } \\
\text { metals } \\
\text { Manufacturing }\end{array}$} & 1 & 1 & 2 & 2 & 3 & 3 & \multirow{4}{*}{$\begin{array}{l}9 \\
8 \\
4\end{array}$} & 1 & 1 & 2 & 2 & 3 \\
\hline & 1 & 2 & 2 & 5 & 1 & 2 & & 0 & 9 & 3 & 8 & 0 \\
\hline & 2 & 6 & 3 & 1 & 1 & 6 & & 4 & 1 & 5 & 0 & 6 \\
\hline & 3 & ? & 2 & 5 & 4 & 4 & & 6 & 7 & 8 & 6 & 7 \\
\hline \multirow{3}{*}{ Equipments } & & & & & & 1 & & & & & & \\
\hline & $\begin{array}{l}3 \\
2\end{array}$ & $\begin{array}{l}4 \\
7\end{array}$ & $\begin{array}{l}6 \\
5\end{array}$ & $\begin{array}{l}7 \\
9\end{array}$ & $\begin{array}{l}9 \\
8\end{array}$ & 0 & $\begin{array}{l}2 \\
3\end{array}$ & $\begin{array}{l}3 \\
8\end{array}$ & $\begin{array}{l}5 \\
4\end{array}$ & $\begin{array}{l}6 \\
3\end{array}$ & $\begin{array}{l}8 \\
9\end{array}$ & $\begin{array}{l}9 \\
5\end{array}$ \\
\hline & 6 & 8 & 6 & 4 & 3 & 9 & 4 & 5 & 2 & 6 & 4 & 8 \\
\hline \multirow{4}{*}{$\begin{array}{l}\text { Other } \\
\text { manufacturing }\end{array}$} & & & 1 & 1 & 1 & 1 & \multirow{4}{*}{$\begin{array}{l}6 \\
0\end{array}$} & & 1 & 1 & 1 & 1 \\
\hline & & 1 & 4 & 4 & 7 & 8 & & 9 & 2 & 3 & 6 & 7 \\
\hline & 2 & 0 & 1 & 6 & 3 & 1 & & 1 & 3 & 0 & 5 & 2 \\
\hline & & & 5 & 7 & 2 & 3 & & 4 & 8 & 6 & 8 & 4 \\
\hline
\end{tabular}




\begin{tabular}{|c|c|c|c|c|c|c|c|c|c|c|c|c|}
\hline \multirow{2}{*}{$\begin{array}{l}\text { Six sub- } \\
\text { industries }\end{array}$} & \multicolumn{6}{|c|}{$\begin{array}{c}\text { Domestic manufacturing enterprises } \\
\text { employee } \\
\text { (Persons number) }\end{array}$} & \multicolumn{6}{|c|}{$\begin{array}{l}\text { Manufacturing enterprises total capitals } \\
\text { (million USD) }\end{array}$} \\
\hline & $\begin{array}{l}2 \\
0 \\
1 \\
0\end{array}$ & $\begin{array}{l}2 \\
0 \\
1 \\
1\end{array}$ & $\begin{array}{l}2 \\
0 \\
1 \\
2\end{array}$ & $\begin{array}{l}0 \\
0 \\
1 \\
3 \\
\end{array}$ & $\begin{array}{l}0 \\
0 \\
1 \\
4\end{array}$ & $\begin{array}{l}2 \\
0 \\
1 \\
5\end{array}$ & $\begin{array}{l}2 \\
0 \\
1 \\
0\end{array}$ & $\begin{array}{l}2 \\
0 \\
1 \\
1\end{array}$ & $\begin{array}{l}2 \\
0 \\
1 \\
2\end{array}$ & $\begin{array}{l}0 \\
0 \\
1 \\
3\end{array}$ & $\begin{array}{l}0 \\
0 \\
1 \\
4\end{array}$ & $\begin{array}{l}2 \\
0 \\
1 \\
5\end{array}$ \\
\hline $\begin{array}{l}\text { Food and } \\
\text { related } \\
\text { Producing }\end{array}$ & $\begin{array}{l}1 \\
1 \\
2 \\
8 \\
6\end{array}$ & $\begin{array}{l}1 \\
4 \\
8 \\
9 \\
4\end{array}$ & $\begin{array}{l}1 \\
8 \\
6 \\
7 \\
5\end{array}$ & \begin{tabular}{|l}
2 \\
1 \\
9 \\
7 \\
2
\end{tabular} & $\begin{array}{l}2 \\
4 \\
2 \\
9 \\
3\end{array}$ & $\begin{array}{l}2 \\
5 \\
6 \\
7 \\
8\end{array}$ & $\begin{array}{l}5 \\
0\end{array}$ & $\begin{array}{l}6 \\
0 \\
8\end{array}$ & $\begin{array}{l}8 \\
8 \\
3\end{array}$ & $\begin{array}{l}8 \\
8 \\
5\end{array}$ & $\begin{array}{l}1 \\
1 \\
1\end{array}$ & $\begin{array}{l}1 \\
4 \\
5 \\
9\end{array}$ \\
\hline $\begin{array}{l}\text { Cloth, shoes } \\
\text { and related } \\
\text { manufacturing }\end{array}$ & $\begin{array}{l}1 \\
9 \\
6 \\
7 \\
8 \\
\end{array}$ & $\begin{array}{l}2 \\
5 \\
2 \\
3 \\
9 \\
\end{array}$ & $\begin{array}{l}3 \\
0 \\
8 \\
9 \\
2 \\
\end{array}$ & $\begin{array}{l}3 \\
5 \\
6 \\
5 \\
9 \\
\end{array}$ & $\begin{array}{l}3 \\
7 \\
5 \\
6 \\
1\end{array}$ & $\begin{array}{l}3 \\
8 \\
2 \\
4 \\
3 \\
\end{array}$ & \begin{tabular}{|l}
1 \\
0 \\
4 \\
8 \\
8 \\
\end{tabular} & $\begin{array}{l}1 \\
3 \\
6 \\
5 \\
5\end{array}$ & \begin{tabular}{|l}
1 \\
9 \\
0 \\
2 \\
\end{tabular} & $\begin{array}{l}2 \\
1 \\
5\end{array}$ & $\begin{array}{l}2 \\
3 \\
5\end{array}$ & $\begin{array}{l}2 \\
3 \\
6 \\
3 \\
\end{array}$ \\
\hline $\begin{array}{l}\text { Chemicals and } \\
\text { related } \\
\text { manufacturing }\end{array}$ & $\begin{array}{l}7 \\
2 \\
3 \\
9\end{array}$ & $\begin{array}{l}9 \\
1 \\
5 \\
6\end{array}$ & $\begin{array}{l}1 \\
1 \\
7 \\
6 \\
5\end{array}$ & $\begin{array}{l}1 \\
3 \\
2 \\
3 \\
1\end{array}$ & $\begin{array}{l}1 \\
5 \\
1 \\
2 \\
3\end{array}$ & $\begin{array}{l}1 \\
5 \\
3 \\
4 \\
0\end{array}$ & $\begin{array}{l}3 \\
0 \\
9\end{array}$ & $\begin{array}{l}4 \\
0 \\
8\end{array}$ & $\begin{array}{l}3 \\
3 \\
4\end{array}$ & $\begin{array}{l}3 \\
3\end{array}$ & $\begin{array}{l}3 \\
7 \\
5 \\
4\end{array}$ & $\begin{array}{l}3 \\
7 \\
1\end{array}$ \\
\hline $\begin{array}{l}\text { Minerals and } \\
\text { metals } \\
\text { manufacturing }\end{array}$ & $\begin{array}{l}1 \\
1 \\
2 \\
5 \\
3\end{array}$ & $\begin{array}{l}1 \\
2 \\
8 \\
4 \\
5\end{array}$ & $\begin{array}{l}1 \\
3 \\
5 \\
2 \\
5\end{array}$ & $\begin{array}{l}1 \\
4 \\
5 \\
6 \\
2\end{array}$ & $\begin{array}{l}1 \\
6 \\
8 \\
9 \\
3\end{array}$ & $\begin{array}{l}1 \\
7 \\
2 \\
5 \\
6\end{array}$ & $\begin{array}{l}4 \\
3 \\
2\end{array}$ & $\begin{array}{l}6 \\
0 \\
7\end{array}$ & $\begin{array}{l}7 \\
0\end{array}$ & $\begin{array}{l}6 \\
5 \\
6\end{array}$ & $\begin{array}{l}8 \\
1\end{array}$ & $\begin{array}{l}8 \\
5 \\
2 \\
2\end{array}$ \\
\hline Equipments & $\begin{array}{l}3 \\
5 \\
7 \\
6 \\
\end{array}$ & $\begin{array}{l}4 \\
9 \\
4 \\
3 \\
\end{array}$ & $\begin{array}{l}5 \\
2 \\
2 \\
1\end{array}$ & $\begin{array}{l}6 \\
7 \\
0 \\
0 \\
\end{array}$ & $\begin{array}{l}6 \\
9 \\
2 \\
7\end{array}$ & $\begin{array}{l}7 \\
1 \\
0 \\
2 \\
\end{array}$ & 8 & $\begin{array}{l}1 \\
6\end{array}$ & $\begin{array}{l}1 \\
7 \\
8 \\
8\end{array}$ & $\begin{array}{l}2 \\
0 \\
5 \\
5\end{array}$ & $\begin{array}{l}1 \\
9\end{array}$ & $\begin{array}{l}2 \\
4 \\
4 \\
\end{array}$ \\
\hline $\begin{array}{c}\text { Other } \\
\text { manufacturing }\end{array}$ & $\begin{array}{l}8 \\
1 \\
6 \\
5\end{array}$ & \begin{tabular}{|l|}
1 \\
0 \\
6 \\
7 \\
3 \\
\end{tabular} & \begin{tabular}{|l}
1 \\
2 \\
6 \\
7 \\
5 \\
\end{tabular} & \begin{tabular}{|l}
1 \\
4 \\
2 \\
9 \\
3 \\
\end{tabular} & \begin{tabular}{|l}
1 \\
5 \\
7 \\
5 \\
2 \\
\end{tabular} & $\begin{array}{l}1 \\
7 \\
0 \\
5 \\
0\end{array}$ & $\begin{array}{l}4 \\
8\end{array}$ & $\begin{array}{l}6 \\
0 \\
6\end{array}$ & $\begin{array}{l}7 \\
7 \\
8\end{array}$ & $\begin{array}{l}9 \\
0 \\
7\end{array}$ & $\begin{array}{l}6 \\
6\end{array}$ & $\begin{array}{l}7 \\
5 \\
1\end{array}$ \\
\hline
\end{tabular}

*Calculated by authors

Tab.5 Panel data results

\begin{tabular}{||c|c|c|c|c|}
\hline & $\begin{array}{c}\text { Parameter } \\
\text { estimation }\end{array}$ & $\begin{array}{c}\text { Standard } \\
\text { error }\end{array}$ & $\begin{array}{c}\text { T } \\
\text { statistics }\end{array}$ & $\begin{array}{c}\text { Associated } \\
\text { probability }\end{array}$ \\
\hline$C$ & 0.7608 & 0.3152 & 2.4137 & 0 .0132 \\
\hline$a$ & 0.4162 & 0.1274 & 3.2669 & 0.0000 \\
\hline$B$ & 0.4591 & 0.1521 & 3.0184 & 0.0000 \\
\hline$Y$ & 0.0827 & 0.0307 & 2.6938 & 0.0000 \\
\hline R-squared & 0.9246 & \multicolumn{2}{|c|}{ F-statistic } & 73465.27 \\
\hline $\begin{array}{c}\text { Adjusted R } \\
\text { squared }\end{array}$ & 0.9005 & \multicolumn{2}{|c|}{ Durbin-Vatson stat } & 1.92 \\
\hline
\end{tabular}

Source: Calculated by authors using EVIEWS 